\title{
THE ROLE OF ASCORBIC ACID IN THE PATHOGENESIS AND TREATMENT OF PRESSURE SORES
}

\author{
By T. Hunter, M.B., B.S.(Lond.) \\ National Spinal Injuries Unit, Stoke Mandeville Hospital, \\ Aylesbury, Bucks. \\ and \\ K. T. Rajan, B.SC., Ph.D.(Cantab), M.B., B.S., D.T.C.D. \\ Rheumatism Research Centre, Stoke Mandeville Hospital, \\ Aylesbury, Bucks.
}

\section{INTRODUCTION}

IT is recognised clinically that direct pressure, protein deficiency (Kermani, Siddiqui, Zain \& Kazi, I970) anaemia (Bain, Crawford \& Ketcham, I966), hypoxia, infection (Smith \& Enquist, 1967) and loss of vasomotor tone plus sensory loss are the major factors in the formation and delayed healing of pressure sores in paraplegic and tetraplegic patients.

It is generally accepted that ascorbic acid is necessary for normal synthesis and continued maintenance of collagen during repair of tissues. The basic defect in collagen synthesis in ascorbic acid deficiency is the inhibited hydroxylation of proline and lysine to hydroxyproline amino acids which are incorporated in the collagen molecule (Robertson, 1964; Stone \& Meister, 1962). In the absence of ascorbic acid, proline and lysine combine to form a high molecular weight polypeptide called protocollagen. In ascorbic acid deficiency there are also changes in the matrix with accumulation of hyaluronic acid (Robertson \& Hinds, 1956) and reduced uptake of 35 S.-sulphate (Reddi \& Norstrom, I954).

Dunphy and Udupa (1955) studied wound healing in two phases. Firstly a 'Productive phase' lasting about 5 days, during which time there is a production of mucopolysaccharides from mast cells and soluble protein precursors of collagen from the fibroblasts. The second or 'collagen phase' lasts from 5 days to the completion of wound healing, during which time normal collagen fibres are formed.

In protein-deficient rats they found a delay in both the productive and collagen phases which could be corrected by methionine. In scorbutic guinea-pigs there was a long productive phase with ample matrix but little production of collagen. Within 48 hours of ascorbic acid administration the wound passes into the collagen phase in which hydroxyproline and well-formed collagen can be demonstrated.

This study was undertaken to assess the role of ascorbic acid in the pathogenesis and treatment of pressure sores in paraplegic and tetraplegic patients.

\section{MATERIALS AND METHOD}

This study was carried out on 18 paraplegic patients varying in age from I6 to $7 \mathrm{I}$ years, nine of whom had pressure sores. The results of their vitamin $\mathrm{C}$ 
TABLE I

\begin{tabular}{|c|c|c|c|c|c|c|c|}
\hline & Age & Sex & Sore & Saturation & Biopsy & Level & Drug treatment \\
\hline & $\begin{array}{l}\text { Normal } \\
\text { Control }\end{array}$ & & & & & & \\
\hline I & 26 & $M$ & 0 & 3 days & 0 & - & \\
\hline 2 & 35 & $M$ & o & 2 days & 0 & - & No drugs \\
\hline 3 & 23 & $M$ & 0 & 4 days & 0 & $\ldots$ & No drugs \\
\hline 4 & 25 & $\mathrm{~F}$ & 0 & 2 days & 0 & - & No drugs \\
\hline 5 & 26 & $M$ & 0 & 2 days & 0 & --- & No drugs \\
\hline 6 & 30 & M & 0 & 3 days & 0 & $\cdots$ & No drugs \\
\hline 7 & 32 & 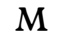 & 0 & 2 days & 0 & - & No drugs \\
\hline 8 & 32 & M & 0 & 2 days & 0 & - & No drugs \\
\hline
\end{tabular}

Paraplegics and Tetraplegics without Sores

\begin{tabular}{|c|c|c|c|c|c|c|c|}
\hline I & 54 & $M$ & 0 & 5 days & 0 & $\mathrm{C}_{4}$ & $\begin{array}{l}\text { Carbachol, G500, } \\
\text { ferrous sulphate Senna } \\
\text { pod granules }\end{array}$ \\
\hline 2 & $2 \mathrm{I}$ & $M$ & o & 3 days & 0 & $\mathrm{C}_{7}$ & $\begin{array}{l}\text { Vit. } B_{12}, \text { Senna pod } \\
\text { granules }\end{array}$ \\
\hline 3 & 32 & $M$ & o & 6 days & 0 & TII & $\begin{array}{l}\text { G.500, Senna pod } \\
\text { granules, Diazepam }\end{array}$ \\
\hline 4 & $4 \mathrm{I}$ & M & 0 & 5 days & 0 & TII & $\begin{array}{l}\text { Carbachol, Senna pod } \\
\text { granules }\end{array}$ \\
\hline 5 & 65 & $M$ & 0 & 3 days & 0 & $\mathrm{~T}_{9}$ & Senna pod granules \\
\hline 6 & 60 & $M$ & 0 & 7 days & 0 & LI & $\begin{array}{l}\text { Gentamycin vit. } \mathrm{B}_{1} \text {, } \\
\text { proestatectomy prior } \\
\text { to test }\end{array}$ \\
\hline 7 & I 8 & M & 0 & 4 days & 0 & $\mathrm{C}_{7}$ & $\begin{array}{l}\text { G5oo, Senna pod } \\
\text { granules, Phenindione }\end{array}$ \\
\hline 8 & 34 & $M$ & 0 & 3 days & 0 & $\mathrm{C}_{7}(\mathrm{I})$ & $\begin{array}{l}\text { Senna pod granules, } \\
\text { Phenindione }\end{array}$ \\
\hline 9 & I 8 & $M$ & 0 & 3 days & 0 & TII & Senna pod granules \\
\hline
\end{tabular}

Paraplegics and Tetraplegics with Sores

\begin{tabular}{|c|c|c|c|c|c|c|c|}
\hline I & $7 \mathrm{I}$ & $M$ & + & Io days & Yes & $\mathrm{L}_{2}$ & $\begin{array}{l}\text { Phenylbutazonè, Iron, } \\
\text { Cloxacillin, Senna pod } \\
\text { granules }\end{array}$ \\
\hline 2 & 57 & $M$ & + & 3 days & Yes & $\mathrm{T}_{4}$ & $\begin{array}{l}\text { Senna pod granules, } \\
\text { Diazepam }\end{array}$ \\
\hline 3 & $2 \mathrm{I}$ & $M$ & + & 7 days & Yes & Tio & Senna pod granules \\
\hline 4 & I6 & M & + & 3 days & - & $\mathrm{T}_{4}$ & $\begin{array}{l}\text { Tetracycline, Phenini- } \\
\text { dione }\end{array}$ \\
\hline 5 & 43 & $M$ & + & 5 days & Yes & TII & $\begin{array}{l}\text { Phenytoin, Phenobarbi- } \\
\text { tone, Cloxacillin }\end{array}$ \\
\hline 6 & 32 & $M$ & + & 7 days & -- & C6 & Six days after operation \\
\hline 7 & 34 & $M$ & + & 5 days & - & $\mathrm{T}_{4}$ & $\begin{array}{l}\text { Orphenadrine, Hydro- } \\
\text { chloride, Trifluropera- } \\
\text { zine }\end{array}$ \\
\hline 8 & 57 & $M$ & + & 4 days & Yes & L2 & Novobiocin \\
\hline 9 & 57 & $M$ & + & 5 days & -- & $\mathrm{C}_{7}(\mathrm{I})$ & Diazepam, Cloxacillin \\
\hline
\end{tabular}

$*$ G500 = Mandelamine $250 \mathrm{mg} .+$ Hexamine Mandelate $255 \mathrm{mg}$. 
saturation tests were compared with the results obtained on eight normal controls varying in age from 23 to 35 years.

The vitamin C saturation test as described by Harris and Abasy (1937) was used as follows:

Each subject was given I gram of vitamin $\mathrm{C}$ daily and all urine passed between the $4^{\text {th }}$ and 6th hours after ingestion of the vitamin $C$ was collected in dark bottles containing $30 \mathrm{cc}$. of glacial acetic acid. Subjects were encouraged to take a good fluid intake based on an average of 5 pints per day to ensure a reasonable urine output during the test period, and only patients with a negligible residual urine or indwelling catheter were included in the series.

The ascorbic acid content of the 2-hour samples was estimated within 2 hours of collection and vitamin $\mathrm{C}$ saturation was taken to be complete when the sample contained more than $50 \mathrm{mg}$. of ascorbic acid. Ascorbic acid estimations were made by titration using 2 to 6 dichlorophenol-indophenol tablets (B.D.H. Poole). A fresh solution was prepared daily.

It was possible in seven of the patients with pressure sores to obtain small biopsies of skin and connective tissue from the edge of the pressure sore. Five of these patients had their sore treated by operation immediately following the vitamin $\mathrm{C}$ saturation test. However, in two cases a further biopsy from an adjacent area was possible following saturation with vitamin $\mathrm{C}$.

The tissues were fixed in formal saline and $6 \mu$ sections were stained with Van Geison's, toluidine blue and Voerhoeff's elastic (Mallory, 1942a, $b$; Pearse, I96I) stain to show the collagen content and pattern of the fibrous tissue.

\section{RESULTS}

Seven out of eight controls reached vitamin C saturation by 72 hours, whereas six out of nine of the group with sores and five out of the nine of the patients without pressure sores took longer than 72 hours to saturate. There is thus some difference between the paraplegic and tetraplegic group and the normal controls in the vitamin $\mathrm{C}$ saturation tests. However, no clear difference emerged between those with and without pressure sores. It is also interesting that a standard daily dose of I g. of vitamin C was used instead of the recommended dose of $70 \mathrm{mg}$. per stone body weight (Harris \& Abasy, I937), and had this latter system been used we might well have found more marked difference between the groups.

Unfortunately the test used is unsatisfactory in some respects due to the possible influence of drugs, especially antibiotics, and could be affected by the presence of infection.

There seemed to be no obvious correlation between the different routine drugs used and results of the vitamin $C$ saturation test. In three patients with indwelling catheters there was a mild urinary infection present, the remainder of the patients having sterile urine. There is evidence suggesting that the level of urinary ascorbic acid is not affected by the presence of bacteria in the urine (Gnarpe, Michaelsson \& Deborg, I968).

Figures I and 2 show the histological picture before and after the administration of ascorbic acid. In the two cases where biopsies were obtained before and after vatiman $\mathrm{C}$ saturation there was a marked increase in collagen formation. In one case the second biopsy was taken only 5 days after the initial dose of ascorbic acid. It has been shown experimentally that collagen formation may be markedly 


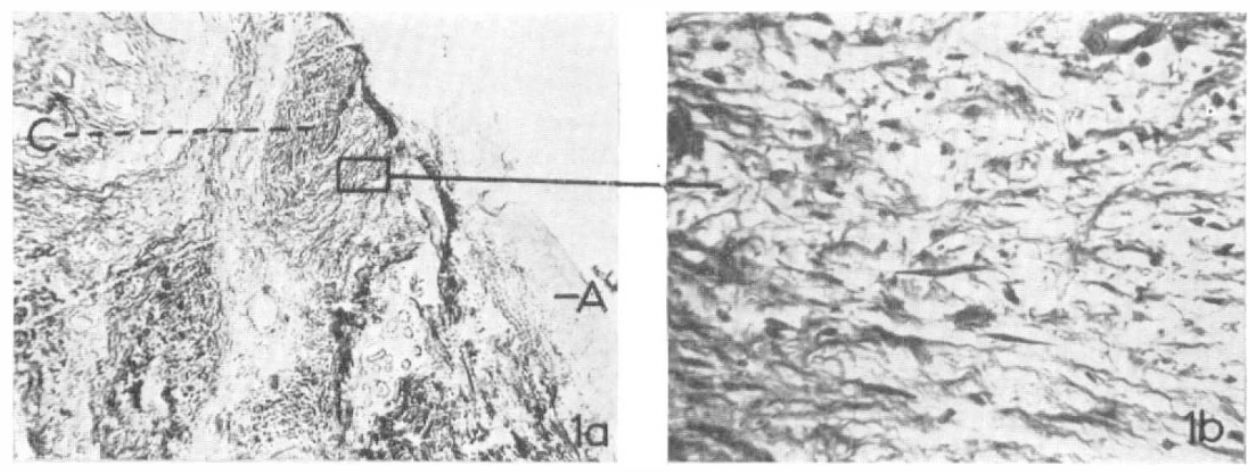

FIG. I

A, Biopsy from edge of bed sore. $\times 59.5 . \quad B$, Higher magnification. Note absence of collagen fibres. $\times 612$.

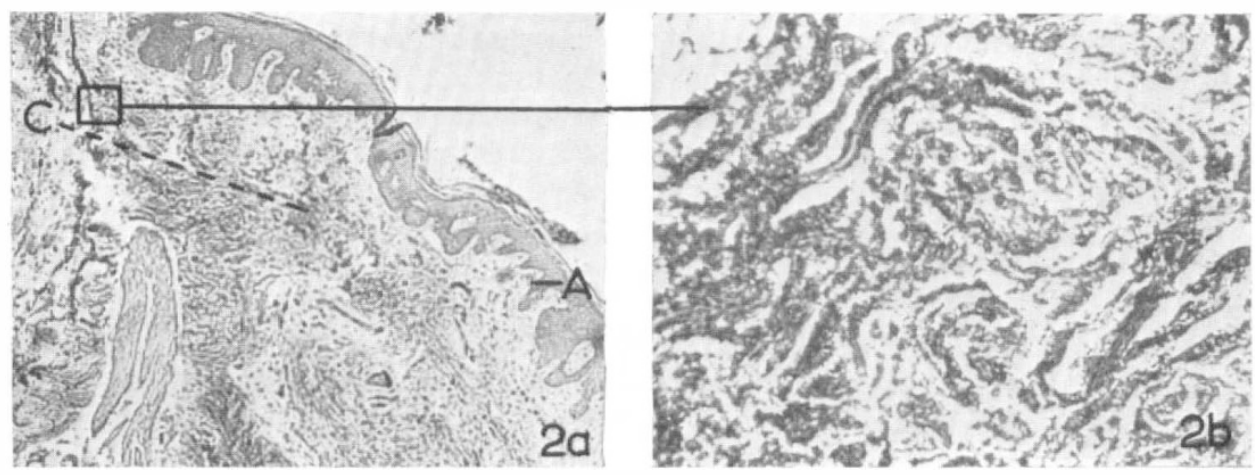

FIG. 2

A, Biopsy from same patient of adjacent area 5 days after $5 \mathrm{gm}$. of vitamin $\mathrm{C} . \quad \times 59.5$ $\mathrm{B}$, Higher magnification. Note bundle of collagen fibres. Toluidine blue. $\times 6 \mathrm{I} 2$. A-Dermis. B-Connective tissue.

increased as early as 48 hours after the administration of vitamin C. Though there was histological improvement in both these cases there was no correlation with their vitamin C saturation tests. The first subject saturated on the 3 rd day, the second only after Io days (fig. 3). There was no correlation between the result of the vitamin $\mathrm{C}$ test and the level of the neurological lesion. There was too great an age scatter to determine any association between age and ascorbic acid status and there was no correlation between the ascorbic acid status and the duration of the paraplegia.

\section{DISCUSSION}

Pressure, protein deficiency and anaemia together with the loss of vasomotor control and sensory loss have already been mentioned as the important aetiological factors in the production of pressure sores in paraplegic and tetraplegic patients 


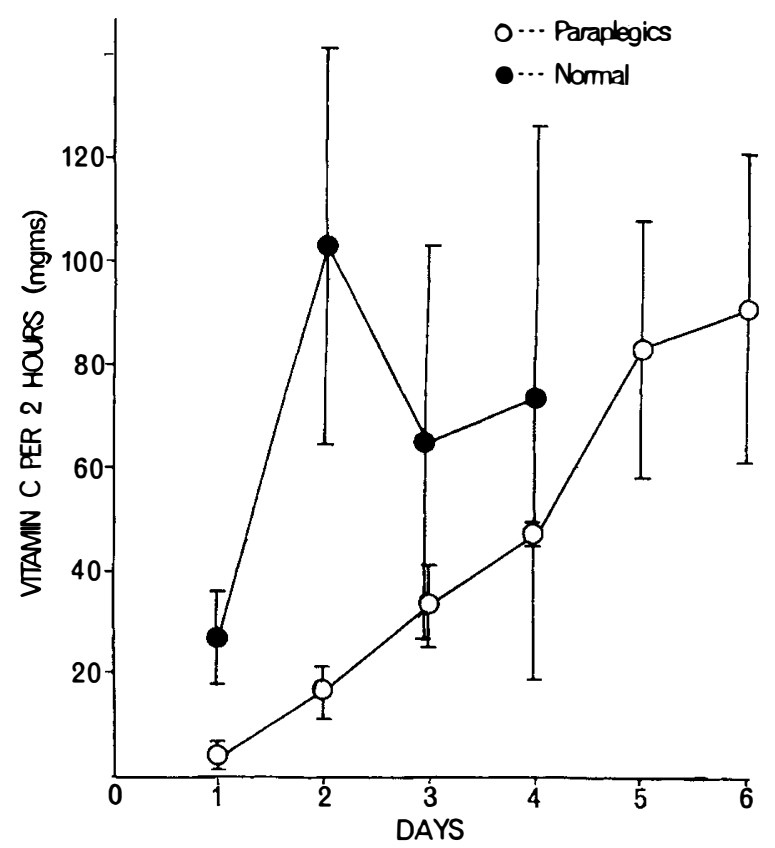

FIG. 3

Graph showing vitamin $\mathrm{C}$ in 2-hour samples. Note that by the 2nd day all the normal subjects are saturated $(>50 \mathrm{mg}$.$) . Compare with paraplegics who$ attained this figure in 5 days. Each point represents the mean \pm standard error of the mean.

and correction of these factors remains the prime need in the treatment of pressure sores; however, the effects of prolonged ascorbic acid deficiency have been recognised for over 220 years (Lind, J. (I747), A Treatise of Scurvy) and the importance of ascorbic acid in the production of collagen is well recognised though its exact role remains unclear. None of our cases showed clinical evidence of ascorbic acid deficiency but the results of the biopsies with improvement of the collagen content suggests that in those cases a relative deficiency of ascorbic acid may have existed and may have led to delayed healing and the production of altered and poorer scar tissue.

The differences shown in vitamin $\mathrm{C}$ saturation between the normal group and the paraplegic/tetraplegic group is of some interest.

In the presence of normal intake it is possible that there is increased utilisation or rapid excretion of the vitamin in these patients, making them relatively deficient. Further work is necessary to establish one of these factors.

\section{CONCLUSIONS}

\section{SUMMARY}

I. In some cases of paraplegia and tetraplegia with pressure sores there exists a relative deficiency of ascorbic acid which may delay wound healing. 
Further investigations of histology and leucocyte vitamin C levels would appear to be indicated.

2. There appears to be a difference between the ascorbic acid status of normal subjects and some paraplegic and tetraplegic patients; the reason for this is not known.

\section{RÉSUMÉ}

Dans quelques cas de paraplégie et de tétraplégie, avec des escarres, il y a présence d'une déficience d'acide ascorbique qui peut freiner la cicatrisation. Des recherches complémentaires devraient être effectuées dans ce domaine. Il semble qu'il y a une différence entre le taux d'acide ascorbique chez les normaux et les paraplégiques et tétraplégiques.

\section{ZUSAMMENFASSUNG}

I. In einigen Fällen von Paraplegie und Tetraplegie mit Druckgeschwūren besteht eine relative Insuffizienz von Ascorbic Acid, wodurch die Heilung verzögert wird. Weitere Untersuchungen der Histologie und Leukocyten in Kombination mit C. Werten sind indiziert.

2. Es scheint eine Differenz zwischen dem Ascorbic Acid Status normaler Individuen und manchen Paraplegikern und Tetraplegikern zu bestehen. Die Ursache hierfür ist unbekannt.

Acknowledgments. The authors would like to thank Dr. J. J. Walsh, M.D., M.R.C.P., F.R.C.S., Director of the National Spinal Injuries Centre, for helpful advice in this work. We are most indebted to the patients and nursing staff without whose help this work would not have been possible.

\section{REFERENCES}

Bain, J. W., Crawford, D. T. \& Ketcham, A. S. (I966). Annals of Surgery, I64, 243. Dunphy, J. E. \& Udupa, K. N. (1955). New England fournal of Medicine, 253, 847.

Gnarpe, H., Michaelsson, M. \& Deborg, Sten (I968). Acta Path. Microbiol. Scandinav. 74, $4 \mathrm{I}$.

HARRIS, L. J. \& Abasy, M. A. (I937). Lancet, 2, I 429.

Kermani, S. R., Siddiqui, M., Zain, S. \& KaZI, K. (I970). Paraplegia, 8, 36.

Mallory, F. B. (1942a). Pathological Techniques, p. I52. Philadelphia: W. B. Saunders.

Mallory, F. B. (I942b). Pathological Techniques, p. I70. Philadelphia: W. B. Saunders.

Muren, A. \& ZEDERFELdT, B. (1966). Acta Chirurgica Scandinavia. 132, 6I8.

Pearse, A. G. (196I). Histochemistry Theoretical and Applied, p. 834. Boston: Little Brown \& Co.

RedDi, K. K. \& Norstrom, A. (1954). Nature, I73, I232.

ROBERTSON, W. VAN B. (I964). Metabolism of collagen in mammalian tissues. In:

Connective Tissue: Intercellular Machromolecules, p. 93. Boston: Little Brown \& Co.

RoBertson, W. VAN B. \& Hinds, H. (I956). Fournal of Biological Chemistry, 221, 79I.

SMith, M. \& ENQUist, I. F. (1967). Surgery, Gynaecology and Obstetrics, 12 5, 965.

Stone, N. \& Meister, A. (1962). Nature, 194, 555. 